Al-Bayyinah: Journal of Islamic Law-ISSN: 1979-7486 (p);

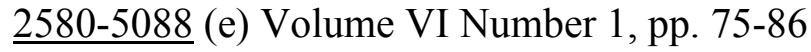

\title{
ANALISIS HUKUM ISLAM TENTANG PELANGGARAN PERJANJIAN PERKAWINAN
}

\section{St. Habibah}

(Dosen Tetap STAI Al-Furqan Makassar, Sulawesi Selatan, Indonesia, email: shabibah34@gmail.com)

\section{Abstract}

A marriage agreement in a marriage bond becomes important if it is actually exercised by the husband and wife and upon mutual agreement. However, the marriage covenant is not always obeyed by the husband and wife or there is a violation in it. The consequences if there is a breach of the marriage agreement whether under Islamic law or positive law is the husband or wife who feels aggrieved over the offense may file a lawsuit either purely civil or place the breach of the agreement as a reason for divorce as in Article 51 Compilation The Islamic law states "Violations of the Marriage Agreement give wife rights for the cancellation of marriage or to propose as a reason for divorce to the Religious Courts.

\section{Kata Kunci: Pelanggaran Perjanjian, Pernikahan, Hukum Islam}

\section{PENDAHULUAN}

\section{A. Latar Belakang Masalah}

Perkawinan merupakan hal yang sangat penting dalam tata kehidupan manusia. Dengan adanya perkawinan, rumah tangga dapat ditegakkan dan dibina sesuai norma dan tata kehidupan masyarakat.

Tujuan perkawinan yakni membentuk keluarga bahagia dan kekal berdasarkan ketuhanan Yang Maha Esa yang 
dalam bahasa Kompilasi Hukum Islam untuk mewujudkan rumah tangga yang sakinah mawaddah warahma. ${ }^{.}$

Allah swt. berfirman dalam Surah An-Nisa: 1 yang berbunyi sebagai berikut:

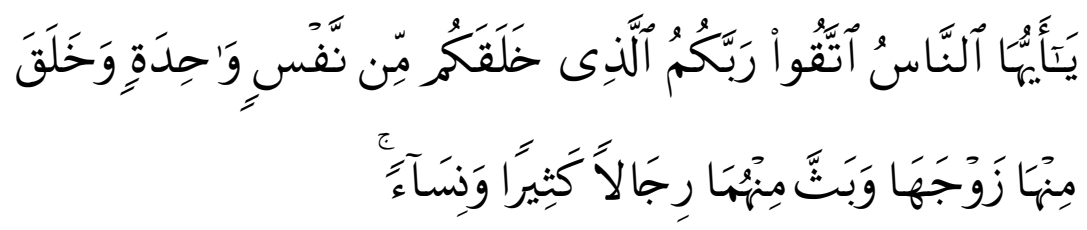

Terjemahnya:

Hai sekalian manusia, bertakwalah kepada Tuhan-mu yang telah menciptakan kamu dari seorang diri, dan dari padanya Allah menciptakan isterinya; dan dari pada keduanya Allah memperkembangbiakkan laki-laki dan perempuan yang banyak.

Pernikahan di samping merupakan anjuran Rasulullah saw. juga sangat diatur pelaksanaannya dalam peraturan perundang-undangan, sebagaimana diatur dalam Undangundang No 1 Tahun 1974 tentang perkawinan. Tujuan dari perkawinan adalah membentuk keluarga yang bahagia dan kekal berdasarkan ketuhanan yang Maha Esa. Pertimbangannya ialah sebagai negara yang berdasarkan pancasila dimana sila yang pertama ialah ketuhanan yang Maha Esa, maka perkawinan mempunyai hubungan yang erat sekali dengan agama. Sehingga perkawinan bukan saja mempunyai unsur lahir atau jasmani tetapi unsur batin atau rohani juga mempunyai peranan penting. ${ }^{2}$

Melihat dari tujuan perkawinan, maka sebelum perkawinan dilangsungkan harus ada persiapan dari kedua calon mempelai. Biasanya persiapan yang dilakukan adalah melakukan sebuah perjanjian perkawinan diantara calon suami dan calon istri.

Namun demikian, perjanjian adalah suatu perbuatan kesepakatan antara seseorang atau beberapa orang dengan

Departemen Agama R.I, Kompilasi Hukum Islam di Indonesia,(Jakarta: Direktorat Jenderal pembinaan keagamaan Islam, 2000), h. 14

2 Idris Ramulyo, Hukum Perkawinan Islam (Cet. IV ; Jakarta : Bumi Aksara. 2002), h. 3 
seseorang atau beberapa orang lainnya untuk melakukan sesuatu perbuatan tertentu. ${ }^{3}$

Perjanjian perkawinan adalah persetujuan yang dibuat oleh calon mempelai pada waktu atau sebelum perkawinan dilangsungkan, dan masing-masing berjanji akan menaati apa yang tersebut dalam persetujuan itu, yang disahkan oleh pencatat nikah. perjanjian nikah tersebut mempunyai syarat dan hukum.

Muatan perjanjian tidak boleh bertentangan dengan alQur'an, karena perjanjian yang bertentangan dengan ketentuan hukum al-Qur'an, meskipun seratus syarat, hukumnya batal. Demikian juga perjanjian yang tidak bertujuan menghalalkan yang haram atau mengharamkan yang halal.

Dalam perkawinan dikenal adanya perjanjian perkawinan yang sering kali dibacakan oleh calon suami setelah akad nikah, yakni adanya perjanjian ta'lik talak. Perjanjian lainnya yang sering dilakukan adalah perjanjian tentang harta bersama.

Menurut hukum Islam pergaulan antara laki-laki dan perempuan melakukan pergaulan suami istri sebelum nikah itu tidak dibolehkan, kecuali sesudah melakukan akad nikah, ijab dan kabul. Sebab itu semata-mata perjanjian perkawinan antara laki-laki dan perempuan atau pertunangan antara pemuda dan pemudi, belum membolehkan bergaulan antara keduanya sebagai suami istri seperti tinggal satu kamar. Hanya pergaulan itu dapat dilakukan sesudah akad nikah, ijab dan kabul. Meskipun belum mengadakan pesta perkawinan, karena pesta perkawinan hanya sunat semata-mata, bukan jadi syarat untuk sahnya perkawinan.

Adapun pergaulan bebas dikalangan remaja, saat ini mencampakan pandangan tentang zina. Akibatnya banyak wanita yang hamil di luar nikah. Tentu keadaan ini tidak dibiarkan begitu saja, bagi orang yang tidak bertanggung jawab akan mengambil jalan mengaborsinya, sedangkan orang yang bertanggung jawab dia akan menikahi wanita tersebut.

Perjanjian perkawinan antara suami istri terutama perjanjian persatuan atau percampuran secara bulat dan harta

${ }^{3}$ Chairuman Pasaribu Suhrawadi K. Lubis, Hukum Perjanjian Dalam Islam, (Cet. I; Jakarta: Sinar Grafika, 1994), h.1 
kekayaan suami istri nampaknya memang sangat ideal bagi pasangan suami istri yang telah berjanji untuk sehidup semati. Tetapi sebenarnya asas persatuan dan percampuran kekayaan secara bulat yang diperjanjikan suami istri tersebut tidak sesuai dengan pandangan hidup bangsa indonesia yang bersifat kekeluargaan atau familiar. Namun, demi kepastian hukum dan demi kemaslahatan kedua belah pihak perjanjian perkawinan dapat dilaksanakan karena tuntutan perkembangan kehidupan manusia.

Pada dasarnya suatu sebab diadakannya perjanjian perkawinan adalah untuk menyimpang dari ketentuan hukum perundang-undangan, yang mengatur bahwa kekayaan pribadi masing-masing suami istri pada asasnya dicampur menjadi satu kesatuan yang bulat. ${ }^{4}$

Dalam arti formal perjanjian perkawinan adalah tiap perjanjian yang dilangsungkan sesuai dengan ketentuan Undang-undang antara calon istri mengenai perkawinan mereka, tidak dipersoalkan apa isinya.

Menurut Wirjono Prodjokoro, kata perjanjian diartikan sebagai "suatu perhubungan hukum mengenai harta kekayaan antara dua pihak, dalam mana satu pihak berjanji atau dianggap berjanji untuk melakukan suatu hal, sedang pihak lain berhak menuntut pelaksanaan janji itu. Dengan demikian kata perjanjian sebagai perhubungan hukum, apabila perhubungan dengan kata perkawinan akan mencakup pembahasan mengenai janji kawin, sebagai perjanjian luhur antara mempelai laki-laki dengan mempelai perempuan, pengertian ta'lik talak sebagai perjanjian atau janji setia dari seorang suami kepada seorang istri, dan pengertian perjanjian perkawinan persatuan dan atau pemisahan harta kekayaan pribadi calon suami dan calon istri yang menjadi objek perjanjian.

Selanjutnya Wirjono juga berpendapat, bahwa perkawinan merupakan suatu perjanjian jika seorang perempuan dan seorang laki-laki berkata sepakat untuk melakukan perkawinan satu sama lain, ini mereka saling berjanji akan taat pada peraturan-peraturan hukum yang berlaku mengenai hakhak dan kewajiban masing-masing pihak selama dan sesudah

\footnotetext{
${ }^{4}$ Ibid., h. 13
} 
hidup bersama itu berlangsung, dan mengenai kedudukan dalam masyarakat dari anak-anak keturunannya.

Dalam suatu perkawinan untuk mengatur dan menjamin hak-hak dari suami istri, maka biasanya membahas mengenai janji kawin, sebagai perjanjian luhur antara mempelai laki-laki dengan mempelai perempuan.

Biasanya perjanjian perkawinan ini dilakukan menjelang perkawinan dilangsungkan serta disahkan oleh pegawai pencatat nikah. Dalam kompilasi hukum Islam (KHI) jelas ditegaskan bahwa perjanjian perkawinan bisa dalam bentuk taklik talak dan bisa dalam bentuk perjanjian lain yang tidak bertentangan dengan hukum Islam.

Isi perjanjian perkawinan dapat mengenai segala hal, asal saja tidak melanggar batas hukum, agama dan kesusilaan. Isi perjanjian tidak melanggar batas-batas hukum misalnya dalam perjanjian ditentukan istri tidak diberi wewenang melakukan perbuatan hukum, karena hukum menentukan bahwa wanita bersuami itu berwenang melakukan perbuatan hukum apapun. Isi perjanjian perkawinan tidak melanggar batas-batas agama, misalnya dalam perjanjian ditentukan istri atau suami tetap bebas bergaul dengan laki-laki atau perempuan lain di luar rumah mereka. Ini jelas melanggar batas agama, sebab agama tidak membenarkan pergaulan bebas semacam itu. Melanggar batas kesusilaan, misalnya dalam perjanjian ditentukan suami tidak boleh melakukan pengontrolan terhadap perbuatan istri di luar rumah dan sebaliknya.

Pasal Undang-undang Nomor 1 tahun 1974 adalah dasar hukum kebolehan bagi calon suami istri untuk mengadakan perjanjian perkawinan dan pasal tersebut merupakan salah satu di antara pasal-pasal dalam Undangundang nomor 1 tahun 1974 yang bersifat pelaksanaan. Sebab masalah harta benda dalam perkawinan telah diatur oleh sistem hukum sebelumnya, yakni menurut pola hukum ada yang berdasarkan pemisahan, dimana semua harta kekayaan pribadi suami istri di bawah penguasaan masing-masing. ${ }^{6}$

5 Damanhuri HR, Segi-Segi Hukum Perjanjian Perkawinan Harta Bersama (Cet. I; Jakarta: CV.Mandar maju, 2007), h. 1-2

${ }^{6}$ Ibid., h. 8-9 
Perjanjian perkawinan bersifat mengikat dan berlaku sebagai undang-undang bagi pihak calon suami atau istri, maka perjanjian perkawinan bukanlah hal yang dianggap remeh oleh calon suami istri karena jika perjanjian perkawinan yang telah dilaksanakan atau pelanggaran terhadap perjanjian dibuat maka secara otomatis memberi hak kepada suami istri sebagai alasan perceraian dan ini menyangkut kelangsungan perkawinan mereka.

\section{B. Rumusan Masalah}

Dari konteks tersebut, perjanjian perkawinan merupakan sesuatu yang urgent dalam perkawinan, karena jika terjadi pelanggaran di dalamnya maka kelangsungan perkawinan terancam putus. Jadi, dalam tulisan ini penulis mencoba melihat dan menganalisis mengenai pelanggaran perjanjian perkawinan menurut hukum Islam.

\section{Kerangka Teori}

Sebelum lebih jauh memasuki pembahasan tentang masalah yang akan dikaji dalam tulisan ini, maka perlu diberikan kata kunci terhadap beberapa ide pokok yang dianggap penting dalam judul ini, yaitu sebagai berikut:

1. Menurut Hukum Islam perkawinan adalah suatu akad yaitu akad yang menghalalkan pergaulan (hubungan suami istri) dan membatasi hak dan kewajiban serta tolong menolong antara laki-laki dan seorang perempuan yang dua-duanya bukan muhrim, artinya apabila seorang pria dan seorang perempuan bersepakat diantara mereka untuk membentuk suatu rumah tangga, maka hendaknya kedua calon suami istri tersebut terlebih dahulu melakukan akad nikah.

2. Menurut pandangan masyarakat, perkawinan merupakan tali ikatan yang melahirkan keluarga sebagai dasar kehidupan masyarakat dan negara. Guna mewujudkan kesejahteraan dan kebahagiaan masyarakat, perlu adanya landasan yang kokoh dan kuat sebagai titik tolak pada masyarakat yang adil dan makmur, hal ini dituangkan dalam suatu Undang-undang Perkawinan yang berlaku bagi semua warga negara di wilayah negara Kesatuan Republik Indonesia. Sebagai negara hukum Indonesia telah mengatur tentang Perkawinan yang tertuang dalam 
Undang-Undang Perkawinan dan telah dilengkapi dengan Peraturan Pemerintah Nomor 9 tahun 1975 yaitu tentang pelaksanaan Undang-Undang No. 1 tahun 1974 tentang Perkawinan, dan Instruksi Presiden Nomor 1 Tahun 1991 tentang Kompilasi Hukum Islam (KHI) dan peraturan-peraturan lainnya mengenai perkawinan.

\section{Metode Penelitian}

Secara metodik, kajian ini menggunakan pendekatan sosiologi hukum, yaitu suatu pendekatan yang digunakan dengan cara mengkaji aspek-aspek sosiologis dari peristiwa hukum, yakni pelanggaran perjanjian.

Teknik pengumpulan data yang digunakan adalah studi kepustakaan. Hal ini dimaksudkan untuk mengetahui konsepkonsep yang bersesuaian dengan penerapan hukum Islam yang diperoleh melalui kajian kitab, buku atau genre karya ilmiah lainnya yang relevan. Studi kepustakaan juga dimaksudkan untuk menganalisis referensi yang signifikan, sehingga memungkinkan dikembangkan atau dibangun sebuah teori baru.

Teknik pengolahan data yang digunakan adalah teknik kualitatif yaitu mengolah data yang tidak dapat diangkakan berdasarkan data-data yang telah dikumpulkan. Sedangkan teknik analisis data yang digunakan adalah:

a. Deduktif, yaitu mengumpulkan fakta-fakta yang bersifat umum untuk kemudian diterapkan pada hal-hal yang bersifat khusus.

b. Induktif, yaitu melihat hal-hal yang bersifat khusus kemudian diterapkan pada hal-hal yang bersifat umum.

c. Komparatif, yaitu membandingkan dua hal atau lebih yang berkaitan dengan masalah penelitian, kemudian dipilih salah satu diantaranya atau mengkompromikan keduanya untuk diterapkan dalam tulisan ini.

\section{PEMBAHASAN}

Perkawinan mempunyai tujuan antara lain membentuk keluarga (rumah tangga) yang bahagia dan kekal berdasarkan Ketuhanan Yang Maha Esa sebagaimana dinyatakan dalam Pasal 1 Undang-undang Perkawinan. Dengan demikian, maka sebenarnya tidak perlu diragukan lagi, apakah sebenarnya yang ingin dicapai dalam perkawinan itu. Namun karena keluarga 
atau rumah tangga itu berasal dari dua individu yang berbeda, maka dari dua individu itu mungkin terdapat tujuan yang berbeda, untuk itu perlu penyatuan tujuan perkawinan demi tercapainya keluarga yang sakinah.

Keluarga merupakan keluarga bahagia bila dalam keluarga itu tidak terjadi kegoncangan-kegoncangan atau pertengkaran-pertengkaran, sehingga keluarga itu berjalan dengan baik tanpa goncangan-goncangan atau pertengkaranpertengkaran yang berarti (free from quarelling).

Tujuan perkawinan yang lain selain membentuk keluarga bahagia, juga bertujuan lain yaitu bersifat kekal. Di Dalam sebuah perkawinan perlu ditanamkan bahwa perkawinan itu berlangsung untuk waktu seumur hidup dan selama-lamanya kecuali dipisahkan karena kematian. Tujuan perkawinan menurut Islam adalah menuruti perintah Allah untuk memperoleh keturunan yang sah dalam masyarakat, dengan mendirikan rumah tangga yang damai dan teratur.7 Hal ini senada dengan firman Allah dalam Al-Qur'an Surah ar-Rum ayat 21 yang artinya: "Dan di antara tanda-tanda kekuasaanNya, Dia (Allah) menciptakan untukmu istri-istri dari jenismu sendiri, supaya kamu cenderung dan merasa tenteram kepadanya, dan dijadikan-Nya di antara kamu rasa kasih sayang. Sesungguhnya pada yang demikian itu benar-benar terdapat tanda-tanda bagi kaum berfikir". Fenomena di dalam masyarakat kadang berbicara lain, perkawinan yang diharapkan sakinah, mawadah, warohmah ternyata karena satu dan lain hal harus kandas di tengah jalan. Kondisi rumah tangga mengalami perselisihan, pertengkaran serta suami istri sudah tidak dapat lagi di damaikan, maka Islam memberi solusi dengan perceraian atau talak. Perceraian atau talak merupakan obat terakhir untuk mengakhiri pertentangan dan pergolakan antara suami istri serta menjadi jalan keluar yang layak untuk keduanya. Kendati dibolehkan Allah membenci perceraian atau talak. ${ }^{7}$

Dalam hal ini, bagi perkawinan yang dilakukan menurut ajaran agama Islam, maka perkawinan tersebut harus dilakukan di hadapan PPN. Di dalam pasal 11 ayat (1) dan (3) dinyatakan bahwa:

7 Saifudin Haris, Perjanjian Perkawinan, http:// hukum.ub.ac.id/ wp.content/uploads (2013/09) 
1. Sesaat sesudah dilangsungkannya perkawinan sesuai dengan ketentuan pasal 10 Peraturan Pemerintah ini, kedua mempelai menandatangani Akta Perkawinan yang telah disiapkan oleh Pegawai Pencatat berdasarkan ketentuan yang berlaku.

2. Dengan penandatanganan Akta Perkawinan, maka perkawinan telah tercatat secara resmi.

Di dalam pasal 11 ayat (1) dan ayat (3) tersebut di atas, dinyatakan lebih jelas bahwa sesaat sesudah perkawinan dilangsungkan, kedua mempelai menandatangani Akta Perkawinan yang telah disiapkan oleh PPN yang turut menghadiri perkawinan tadi, dan dengan penandatanganan Akta Perkawinan tadi, maka perkawinan itu telah tercatat secara resmi menurut hukum, dan kepada masing-masing suami istri diberi satu salinan Akta Nikah tersebut.

Dengan diberikannya Akta Nikah kepada masingmasing suami istri, maka perkawinan mereka telah dinyatakan sebagai perkawinan yang harus dilindungi oleh hukum serta adanya hubungan hukum nikah suami istri telah diakui dan dilindungi oleh hukum.

Perkawinan yang dilakukan secara rahasia (sirri) pada dasarnya adalah kebalikan dari perkawinan yang dilakukan menurut hukum, dan perkawinan menurut hukum, adalah seperti yang telah diuraikan di atas. Dengan demikian, maka dapat dijumpai sebuah makna normatif bahwa perkawinan yang dilakukan secara sirri adalah perkawinan yang dilakukan tidak menurut hukum.

Dilihat dari segi hukum, suatu tindakan yang dilakukan menurut hukum baru dikatakan sebagai perbuatan hukum, dan oleh karena itu maka berkait hukum (yakni akibat dari tindakan itu mendapat pengakuan dan perlindungan hukum). Sebaliknya suatu tindakan yang dilakukan tidak menurut aturan hukum, tidak dikatakan sebagai perbuatan hukum, sekalipun tindakan itu belum tentu melawan hukum dan karena sama sekali belum mempunyai akibat yang diakui dan dilindungi dan atau dilindungi oleh hukum.

8 Saifudin Haris, Suatu Tinjauan dan Ulasan secara Sosiologi Hukum, (Cet.I; Jakarta : Pradnya Paramita, 1986), h. 126 
Sejalan dengan kerangka teoritik itu, akad nikah dilaksanakan dapat berupa dalam dua wujud, yaitu: pertama, akad nikah semata-mata hanya menurut ketentuan pasal 2 ayat (1) undang-undang perkawinan tersebut, yakni tata cara agama saja, dan kedua, akad nikah yang dilakukan menurut ketentuan pasal 2 ayat (1) yakni mengenai tata cara agama dan ayat (2) yakni mengenai pencatatan nikahnya oleh PPN secara simultan. Apabila wujud akad nikah yang pertama dipilih, maka perkawinan itu telah sah menurut ajaran agama sesuai dengan permintaan pasal 2 ayat (1) UUP tersebut, dan belum termasuk kategori perbuatan hukum sehingga belum mendapat pengakuan secara hukum. ${ }^{9}$

Perbuatan nikah baru dikatakan perbuatan hukum apabila memenuhi unsur tata cara agama dan tata cara pencatatan nikah. Kedua unsur tersebut berfungsi secara kumulatif dan bukan alternatif. Unsur pertama berperang sebagai pertanda sah dan unsur kedua sebagai pertanda perbuatan hukum.

Dari uraian di atas dapat disimpulkan bahwa terdapat pembagian antara tanda sah dengan tanda perbuatan hukum. Tanda perbuatan hukum menjadi syarat pengakuan dan perlindungan terhadap tanda sah. Dengan kata lain kalau akad nikah menurut agama Islam tidak dilakukan menurut kehendak unsur tata cara pencatatan nikah, maka berakibat belum memperoleh pengakuan dan perlindungan hukum terhadap akad nikah tersebut berupa perolehan akta nikah.

Di dalam pasal 5 ayat (1) Kompilasi Hukum Islam juga menegaskan: "Agar terjamin ketertiban perkawinan bagi masyarakat Islam, setiap perkawinan harus dicatat". Kemudian pada pasal 6 ayat (1) dan (2) dinyatakan bahwa:

(1) Untuk memenuhi ketentuan dalam pasal 5, setiap perkawinan harus dilangsungkan di hadapan dan di bawah pengawasan pegawai Pencatat Nikah.

(2) Perkawinan yang dilakukan di luar pengawasan pegawai Pencatat Nikah tidak mempunyai kekuatan hukum.

${ }^{9}$ A.Gani Abdullah, Tinjauan Hukum terhadap Perkawinan di bawah Tangan, Mimbar Hukum, No.23 Tahun VI,Nopember - Desember 1995, h. 48. 
Selanjutnya pada pasal 7 (1) juga menegaskan: "Perkawinan hanya dapat dibuktikan dengan Akta Nikah yang dibuat oleh pegawai Pencatat Nikah". ${ }^{10}$

Perjanjian perkawinan dibuat atas kesepakatan bersama antara suami dan istri akan tetapi, tidak selamanya akan ditaati oleh suami istri persoalan yang akan dianalisis adalah bila terjadi salah satu pihak tidak menepati isi perjanjian (ingkar janji). Dalam hal ini dapatkah yang merasa dirugikan (suami atau istri) mengajukan gugatan, baik yang bersifat keperdataan murni atau menempatkan pelanggaran perjanjian itu sebagai alasan perceraian.

\section{KESIMPULAN}

Perjanjian perkawinan diatur dalam kompilasi hukum Islam pada bab VII dan dalam Undang-undang No. 1 tahun 1974 tentang pernikahan serta terdapat juga di KUHPerdata. perjanjian perkawinan dalam sebuah ikatan perkawinan menjadi penting apabila hal itu benar dilaksanakan oleh suami istri dan atas kesepakatan bersama. Akan tetapi, tidak selamanya perjanjian perkawinan tersebut ditaati oleh suami istri atau terjadi pelanggaran di dalamnya. Maka dari itu, konsekuensi jika terjadi pelanggaran perjanjian perkawinan baik menurut hukum Islam maupun hukum positif adalah pihak suami atau istri yang merasa dirugikan atas pelanggaran tersebut dapat mengajukan gugatan baik yang bersifat keperdataan murni atau menempatkan pelanggaran perjanjian itu sebagai alasan perceraian sebagaimana pada Pasal 51 Kompilasi Hukum Islam menyebutkan "Pelanggaran atas perjanjian Perkawinan memberi hak kepada istri untuk pembatalan nikah atau mengajukan sebagai alasan perceraian ke Pengadilan Agama.

10 Departemen Agama RI, Kompilasi Hukum Islam diIndonesia, (Jakarta: Direktorat Pembinaan Kelembagaan agama Islam, 1997/1998), h. 15. 


\section{DAFTAR PUSTAKA}

Abdullah, Gani, Tinjauan Hukum terhadap Perkawinan di bawah Tangan, Mimbar Hukum, No.23 Tahun VI, Nopember - Desember 1995

Aziz, Abdul, Muhammad Azzam, Fiqh Munakahat Khitbah, Nikah Dan Talak, Cet. II; Jakarta: Bumi Aksara, 2011

Chairuman Pasaribu Suhrawadi K. Lubis, Hukum Perjanjian Dalam Islam, Cet. I; Jakarta: Sinar Grafika, 1994

Damanhuri HR, Segi-Segi Hukum Perjanjian Perkawinan Harta Bersama, Cet. I; Jakarta: CV.Mandar maju, 2007

Departemen Agama RI, Kompilasi Hukum Islam, Jakarta : Direktorat Jenderal Kelembagaan Agama Islam, 1997/1998

Departemen Agama RI, Kompilasi Hukum Islam di Indonesia, Jakarta: Direktorat Jenderal pembinaan keagamaan Islam, 2000

Departemen Agama RI, Kompilasi Hukum Islam di Indonesia, Jakarta: Direktorat Pembinaan Kelembagaan agama Islam, 1997/1998

Idris Ramulyo, Hukum Perkawinan Islam, Cet. IV ; Jakarta: Bumi Aksara. 2002

Manan, Abdul, Reformasi Hukum Islam di Indonesia, Ed. I, Cet. I; Jakarta: PT. Raja Grafindo Persada, 2006

Salim, Pengantar Hukum Perdata Tertulis (BW), Cet. I; Yogyakarta: Sinar Grafika. 2001

- Suatu Tinjauan dan Ulasan secara Sosiologi Hukum, Cet.I; Jakarta: Pradnya Paramita, 1986

Syarifuddin, Amir Garis-Garis Besar Fiqh, Cet. I; Jakarta: Prenada Media, 2003

Thalib, Muhammad, Manajemen Keluarga Sakinah, Cet. 2; Yogyakarta: Pro-U Media. 2008 